\title{
Municipal Solid Waste Disposal Site Selection Using Remote Sensing Technology and AHP Process (Case Study: Khesht city, Fars Province, Iran)
}

\author{
Amirhossein Dashtian ${ }^{\text {(iD) }, \text { Abdulmannan Rouhani*2 (i) , Arash Dashtian }}{ }^{3}$ (D) \\ ${ }^{1}$ Ms.c,of Environmental Science and Municipal Clerk, Kesht City, Iran. \\ ${ }_{2}^{2}$ Ms.c, of Environmental Science, Yazd University, Iran \\ ${ }^{3}$ Municipal Clerk of Kazerun City, Iran.
}

\section{Keywords}

Landfill,

site selection,

Remote sensing,

GIS,

Khesht.

\begin{abstract}
The design and implementation of the municipal waste management system aim to solve the urban issues and ultimately contribute to the citizens' health and welfare. The first step in this system is to select a site for the safe disposal of wastes. This survey aimed to select the most suitable landfill site for municipal solid waste using the geographic information system (GIS) and the analytic hierarchy process (AHP) model following the environmental, economic, and engineering criteria. Therefore, by reviewing the literature and backgrounds, the parameters required for locating the landfill site were extracted, and the most important ones (15 sub-criteria) were selected and divided into four groups. The results showed that the sub-criterion of distance to the river with the weight of 0.218 was identified as the most critical parameter, followed by groundwater depth. In this way, the flooding parameter with the weight of 0.010 was considered the least important variable. In addition, it was found that the moderate suitability class with $50 \%$ of the area had the highest area, and the very high suitability with $0.8 \%$ had the lowest area. The inconsistency rate was equal to 0.04 , which illustrates the high consistency of matrices. Then, the overlaying was carried out, and three sites were determined as the best place for a landfill in Khesht county.
\end{abstract}

\section{Introduction}

In recent years, the increasing growth of the urban population has been combined with population centers and the development of urban areas based on the comprehensive national plan (spatial planning). On the other hand, the development of mechanical and modern life relationships resulting from the expansion of the geographical boundaries of capitalism has put the places under pressure more than ever. One of the environmental consequences of this pressure is the changes in consumption patterns and dietary habits and the increase in the packaging materials for the reasons mentioned, resulting in the exponential increase in municipal solid waste. Currently, the disposal of wastes resulting from consumerism is one of the significant and costly problems for most urban managers. Waste generation is one of the most critical sources threatening public health and the global environment.

Mainly, in most developing countries, municipal solid waste storages are in excavated or open landfills. Because of urban sprawl, lack of adequate solid waste management practice, weak planning, and scarcity of resources, developing countries have significant municipal solid waste management problems[1]. Landfilling has been the most effective disposal method in different countries, even in developed countries [2]. Like any other engineering project, a landfill needs basic information and meticulous planning. The selection of multiple variables creates multiple data layers, and trying to find a suitable solution for analyzing a large number of data layers and obtaining the correct result will unconsciously drive decision-makers to use the systems that, in addition to high accuracy, have high performance in terms of the operation speed and the ease of implementation [3].

Selecting the optimal landfill site requires multi-criteria decisionmaking (MCDM), one of the most critical consequences of waste management. As regards decision makers, decision making in multicriteria challenges is a subjective process [4]. Several MCDM methods can be applied for landfill site selection. Analytical hierarchy process (AHP) is one of the methods applied to decide for multi-criteria variables and can minimize complex decisions to a multiple binary comparison and consistency [5]. In other words, it can assist all decision-makers to logically choose and set priorities for complex decision problems [6]. Satty [7] was the first one who suggested the AHP, and it is claimed to be one of the best decision-making techniques. It is one of the more broadly systems planned for making multi-criteria decisions as it conveys the anticipation for developing problems hierarchically [8]. It is a powerful and flexible instrument for the quantitative and qualitative study of multi-criteria challenges [9]. AHP is described regarding paired comparisons since it is helpful in decomposing complicated matters with multiple criteria within several matched comparisons [10]. This method allows the problem separations within a hierarchy of sub-problems that are more easily assessed and easier to understand. Subjective assessments are changed into numerical values on a numerical scale [11]. It is one of the most comprehensive MCDM tools [12].

AHP is a popular and influential method that can be used in a GIS environment and prepares an alternative for analyzing complicated challenges that enable objective and subjective factors to be considered in decision-making [13]. Recently, the Geographic Information System (GIS) has been established as a comfortable tool for apply in landfill site-selection surveys. GIS is a computer-assisted decision system for supporting with the potential to analyze, manage and represent geospatial reference data [14]. Moreover, MCDM is a famous method for resolving complex decision-making issues in waste-disposal site selection [15]. Saaty suggested AHP as a sort of MCDM method in which a problem is broken down through a hierarchy, where the purpose remains superior [16]. Site selection methodology based on GIS combines MCDM techniques and spatial 
analysis tools given by GIS to assess the entire region in terms of the assessment criteria (hydrological/hydrogeological, environmental, social, and technical/economic) [4]. GIS can be applied to create interactive queries, edit data in maps, analyze spatial information and display spatial or geographic results of all these processes [17].

GISs present appropriate manipulation and data presentation and can manage a large part of spatially distributed data from diverse sources as it effectively recovers, stores, assesses, and displays information based on user-defined specifications [18]. At the same time, AHP assists in ranking appropriate sites and choosing the best option as it supplies a stable ranking of the potential landfill areas relying on several available criteria [19]. Many researchers [20; 21; 22] have been used the GIS-based AHP method to identify suitable sites for landfills. These researchers considered many criteria, including geology/hydrology, land use, slope, altitude, aspect, distance from the settlement, surface water, roads, and protected areas (ecological, scientific, or historical) for their study. Others, such as Barakat et al. [23], have used Boolean and AHP methods to validate that $54 \%$ of the landfill sites were unsuitable in Morocco Khouribga. In their study, many criteria including, distance from residential areas, distance from faults, distance from roads, elevation, slope, aspect, geology, distance from surface water, groundwater, land use wise many criteria have been used. Islam et al. [24] have applied the AHP-GIS integration to choose suitable landfill sites in Pakistan, Islamabad, and Rawalpindi. Their results indicated that $34 \%$ of the study area were unsuitable, and $20 \%$ were highly suitable. Khodaparast et al. [25] have utilized the AHP-GIS integration to study the anticipated criteria for Qom, Iran. The results showed that $62 \%$ of the study area had been determined as unsuitable, $31 \%$ low suitable, and $7 \%$ suitable and highly suitable.

Several criteria are involved in the landfill site selection studied in three categories: physical, environmental, and socio-economic. They include the land slope, wells and springs, surface water resources, faults, wind, rainfall, groundwater depth, soil characteristics, and flooding with a 100-year return period [26]. Improper waste disposal sites have major environmental issues on soil fertility, water resources, landscape view, and natural habitats [27]. It is crucial to consider all environmental standards for disposal site selection to diminish these significant environmental problems. Moreover, due to financial costs and social conflicts, some factors such as economic and social have a crucial role in selecting landfills [28]. Generally, all the significant harmful effects observed in the area should be considered during the site selection process. It can be stated that the proper site selection can allay more than half of the concerns over the landfill. The design and implementation of the municipal waste management system aim to solve the urban issues and ultimately contribute to the citizens' health and welfare.

Lack of attention to the environmental issues in many cities worldwide threatens the landfill environment and its adjacent habitats as a hidden enemy and inflicts irreparable damage to the natural environment and human communities. The environmental management of the landfill site should be considered to avoid the potential hazards of municipal solid waste, and the environmental parameters should be considered in the site selection. To avoid the adverse effects of the landfill, we will have to adhere to some principles for the site selection. The site should be located where it does not contaminate the surface and groundwater resources; there is sufficient, relatively flat land with no usable soil, it does not adversely affect the landscape and ecology of the area, the wind cannot transfer the odor and pollutants to the city space, there is no encroachment into other urban areas. These are the factors contributing to the selection of landfill sites. Given that the current landfill site of Khesht is not suitable, the purpose of this study is to use the GIS and AHP model for selecting the most suitable site for the disposal of municipal solid waste in Khesht following the environmental, economic, and engineering criteria.

\section{Materials and methods}

\subsection{The study area}

Kazerun County, with an area of $4059 \mathrm{~km} 2$, covers $3.3 \%$ of the province area and is located in 51.24 to 52.122 east longitude and 29.05 to 29.91 north latitude. The county has six cities: Baladeh, Kenar Takhteh, Khesht, Nodan, Ghaemieh, and Kazerun. Khesht is one of the five districts of Kazerun county. This district is bounded on the north by Mamasani, on the east by Kazerun, on the south by Borazjan, and on the west by Saadabad. It is situated in a mountainous and plain area with an altitude of $525 \mathrm{~m}$. The geographical coordinates of Khesht are $29^{\circ} 33^{\prime} 52^{\prime \prime}$ north latitude and $51^{\circ} 20^{\prime} 13^{\prime \prime}$ east longitude ad the topography of the study area is mostly hilly and mountainous. The climate of the region is hot and dry. In terms of groundwater, the depth of groundwater is more than 50 meters. The region's soil is finegrained with low permeability, and there is no particular vegetation in the area. The profession of most people in the area is agriculture and palm cultivation, and the area has a hot arid climate and is covered with palm trees, which makes it a socially sensitive task to find the proper landfill site. The location of Khesht is illustrated in Fig. 1.
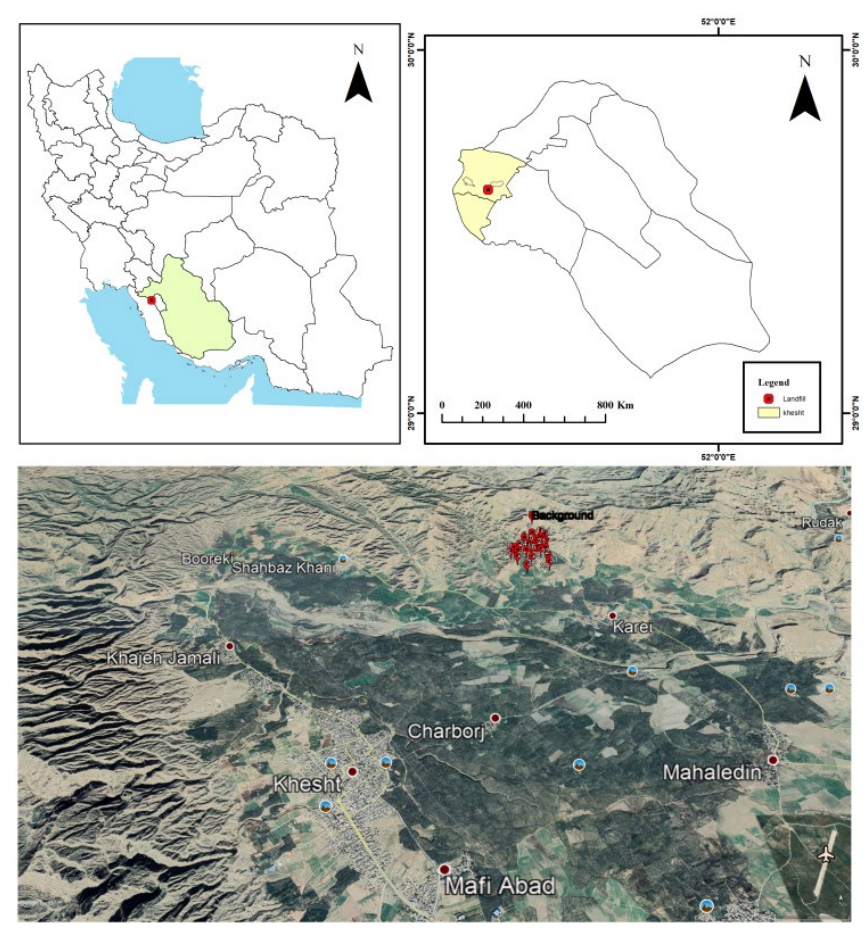

Figure 1. Location of the study area

\subsection{Methodology}

The method used in this study consists of identifying and selecting the criteria affecting the selection of the Khesht landfill site, weighting and prioritizing different criteria for the study area, mapping and then overlaying the criteria, and finally, identifying the appropriate areas for the desired use.

Based on the list of identified factors, the maps and data for each factor are collected from available sources. Each part of the sources may be prepared from different organizations or in different formats and scales. The point is that the nature and scale of the information should be commensurate with the needs. The maps used in these studies include the 1: 25000 topographic maps of the national cartographic center (NCC) and digital elevation model (DEM) (obtained from NCC), 1:100000 geological maps prepared in the Geological Survey, economic and social environment information obtained from the Census Bureau, land use information and maps, vegetation, political divisions, and pedology from the Forest and Rangeland Organization.

The Arc GIS 10.2 software suite was used for the preparation, overlaying, analysis, and all mapping tasks. Finally, Expert Choice software was used to weight the criteria and complete the AHP process. 
The first essential step in selecting a site project is the criteria selection to evaluate the suitability of the land to gain the objectives. Hence, after consultations with regional experts and reviewing relevant international literature, four criteria were selected environment, technical-operational, physical, and socio-economic. In this study, fifteen criteria were selected, and the main criteria were categorized into three groups (Table 1). The first group was environmental criteria, including distance to industrial centers, distance to the river, land use, and groundwater resources. These criteria were taken into account to decrease hazards resulting from groundwater contamination, such as leachate pollution [29]. Environmental criteria are critical due to various pollutants are released to the environment from MSW landfills through landfill leachates or landfill gases, and these exhibit a critical risk to the surrounding environment [30]. The second group, Technicaloperational criteria, should be the primary concern in the distance to the dam and the road. The third group, Socio-economic criteria, concern the distance to residential areas (urban and rural) and distance to agricultural lands. This criterion concerns the ecology of the study area, which aims to prevent aesthetic and economic damage to candidate sites due to MSW landfills [15]. The fourth group, Physica criteria, concern the distance to faults, soil texture, geology, slope, and distance to flood-prone areas.

The data to be collected is provided by various organizations and companies for their purposes. For this reason, the data often has different properties (such as format, scale, image system). Depending on the project's purpose, it is necessary after performing the analysis to convert the collected data to the format used in the software in the same scale and image system so that reliable results can be obtained after the site selection. These processes include the following operations:

- Control of the land use range accuracy from Google earth software

- Integration (Union) of similar land uses in the land use map.

- Separation (Clip) of information according to the intended purpose.

The data used in this study were obtained from the NCC and Khesht Municipality. The specifications of the sheets prepared by the NCC are as follows.

\subsubsection{Analytic hierarchy process (AHP)}

AHP enables decision-makers to determine the interplay of many complex and uncertain situations. This process helps decisionmakers set their priorities based on goals, knowledge, and experience to consider their feelings and judgments [31]. The AHP is one of the most exhaustive systems designed for multiple-criteria decisionmaking. It allows the problem to be formulated hierarchically and makes it possible to consider different quantitative and qualitative criteria. It also shows the degree of consistency and inconsistency of the decision, which is one of the advantages of this technique in the multi-criteria decision-making process. This method is designed based on the analysis of the human brain for complex and fuzzy problems. In this method, the problem should first be hierarchically divided into smaller components. The components include the goal setting, criteria, and alternatives. Then, each option is obtained using the pairwise comparison method, and the top option is selected.

The hierarchy is a graphical representation of a real complex problem, at the top of which is the overall goal of the problem, and in the following levels, there are criteria and alternatives, although there is no constant and definite rule for drawing the hierarchy. The hierarchy may be as one of the following forms:

Goal - Criteria - Sub-criteria - Alternatives

Goal - Criteria - Factors - Sub-factors - Alternatives

The scoring system in this method is based on a 9-point spectrum. The weights are assigned to the criteria to prioritize between different criteria. For this purpose, in this study, each group was given a weight to prioritize each environment. The weighting in this section is relatively done to prioritize the criteria. The weighting of the environments was done by the pairwise comparison method. Consistency index (CI) was reported in Saaty $[7 ; 16]$ and is shown in Eq (1) as:

$$
C I=\frac{\lambda_{\max }-n}{n-1}
$$

Where $\lambda \neg \max$ is the maximum eigenvalue, $\mathrm{n}$ is the number of factors in the judgment matrix. Consistency ratio (CR) was as indicated in Saaty $[7 ; 16]$ and is shown in Eq. (2) as:

$$
C R=\frac{C I}{R I}
$$

Where RI is the consistency index of a randomly generated Reciprocal matrix from the 9-point scale, with forced reciprocals.

In this study, the AHP was used to weight the criteria. In order to evaluate any subject, we need a measure or criterion. Choosing the right criteria allows us to make a proper comparison between the alternatives. However, the evaluation task becomes more complex when multiple criteria are considered for the evaluation, and the task complexity is increased when there is a conflict and disparity between the multiple criteria. At this time, the evaluation and comparison go beyond the simple analytical mode the mind can, and the practical analysis tools would be required. One of the powerful tools for such a situation is the AHP. The procedure of the AHP modeling is begun with identifying the elements, making decisions, and prioritizing. The elements are different ways of doing the work and prioritizing the measures.

Previous investigations have variously applied the consultation of two, three, and five experts. However, in our study, a total of 16 experts in the field of municipal waste site selection and management were consulted, whose specialties are as follows: (1) Three Ph.D. in Environmental science familiar with urban planning issues. (2) Ten environmental experts working in the municipalities of the province. (3) Three senior urban management experts working in the urban planning sector.

\subsubsection{Create required layers}

Different data were extracted from the 1:2000 map of Municipality Cooperation Organization and Khesht Municipality and the 1:25000 map of NCC, and the data preparation processes were implemented for the introduction into the GIS system. A descriptive table was designed for each information layer according to the research requirements and the obtained descriptive information. Finally, the information layers were created as feature classes in the Personal Geodatabase format of ArcGIS 10.2 software.

As the 1:2000 and 1:25000 Khesht data was stored in dwg (AutoCAD) format, the exact location of each effective user was determined after the transfer to ArcGIS 10.2 software. The first step of the required practical steps is separating the details and extracting the required information layers during this process. Therefore, according to the factors' needs and characteristics, each criterion's spatial layers were prepared. Then, the data was stored in a coherent and organized manner in the Personal Geodatabase.

The required layers based on the AHP table (Table 1) are as follows:

Table 1 suitable criterion for municipal waste disposal site

\begin{tabular}{lll}
\hline & Criteria & Sub-criteria \\
\cline { 2 - 3 } & & \\
& Socio-economic & Distance from urban areas \\
Selection of & & agricultural lands \\
Site & & Surface water sources \\
& & Lnvironmental
\end{tabular}

Distance from industrial areas

Groundwater depth

Distance from the access road 


$\begin{array}{ll}\begin{array}{l}\text { Technical- } \\ \text { operational }\end{array} & \text { Distance from dam } \\ & \text { Slope } \\ & \text { Soil type } \\ \text { Physical } & \text { Distance from fault } \\ & \text { Geology } \\ & \text { Distance from flooding }\end{array}$

\section{Results and discussion}

Selecting the suitable landfill site as a case study of Khesht City, including GIS and remote sensing with AHP, was carried out in this study by specifying the weights for all criteria by the AHP technique. In total, fifteen parameters were considered within the headings of Socio-economic, environmental, Technical-operational, and Physical perspectives relying on regional experts' judgments and guidelines obtained from relevant literature.

\subsection{Information layer processing}

\section{Socio-economic criteria}

Distance from urban and rural areas: Landfill sites near urban and rural areas can result in many environmental and health issues [32]. As a result of air, visual water contamination, vermin, and insects, harmful odor, noise, and fire, landfill sites should be selected at a distance from urban and rural areas [23]. Different threshold values were applied to choose suitable landfill sites [33]. As reported by European legislation, landfill sites should not select at a distance of fewer than $500 \mathrm{~m}$ from residential areas [15]. Furthermore, based on the standard formulated by EPA for landfill site selection, areas that are at a distance of fewer than $300 \mathrm{~m}$ from residential areas are unacceptable, areas at distances between $300 \mathrm{~m}-500 \mathrm{~m}$ are less acceptable, areas that are at distances between $500 \mathrm{~m}-800 \mathrm{~m}$ are moderately acceptable and areas that are at a distance of larger than $800 \mathrm{~m}$ are highly acceptable. For this criterion, the minimum distance from the landfill site to the residential areas is $300 \mathrm{~m}$. As this distance is increased, the suitability is also increased. Therefore, the distance map of each factor (rural and urban areas) was separately prepared by applying the Euclidean distance function. The resulting map was standardized using the fuzzy membership function in a linear decreasing manner so that the closest distance to the existing rural and urban population centers was less valuable than the farther distance. Fig. 2 (a) shows the map of distance from the population centers of the city, and Fig. 2 (b) shows the map of distance from the rural areas.

Agricultural lands: Selecting a suitable landfill site is directly related to the price and type of land use and significantly affects the disposal cost per one ton of waste and the cultivated lands. Also, selecting a site suitable for the landfill will destroy the plant species and vegetation of the area. Therefore, the ecological value of the plants in the area should be carefully considered during the decision-making. Thus, the map of distance from agricultural areas was prepared, and standardized where the areas closer to the existing agricultural lands have less value than the farther distance. The Small function is used for this purpose. Fig. 2 (c) shows the map of distance from the agricultural areas.

\section{Environmental criteria}

Land use: Land use is vital to sorting out scuffles of the approval of unnecessary landfill amenities and a significant indicator of spatial impact extent [34]. Thus, the aim of considering this criterion is to prevent selecting an area for landfill with high productivity or development [35]. The land-use buffer map was considered to prevent difficulties resulting from landfills sited within the study area. The existing land use maps were also standardized according to the importance of each land use in the landfill site with the review of available literature and standards. Then manually standardized due to the nature of these types of maps. Fig. 3 ((a) and (b)) shows the land use and classified map.

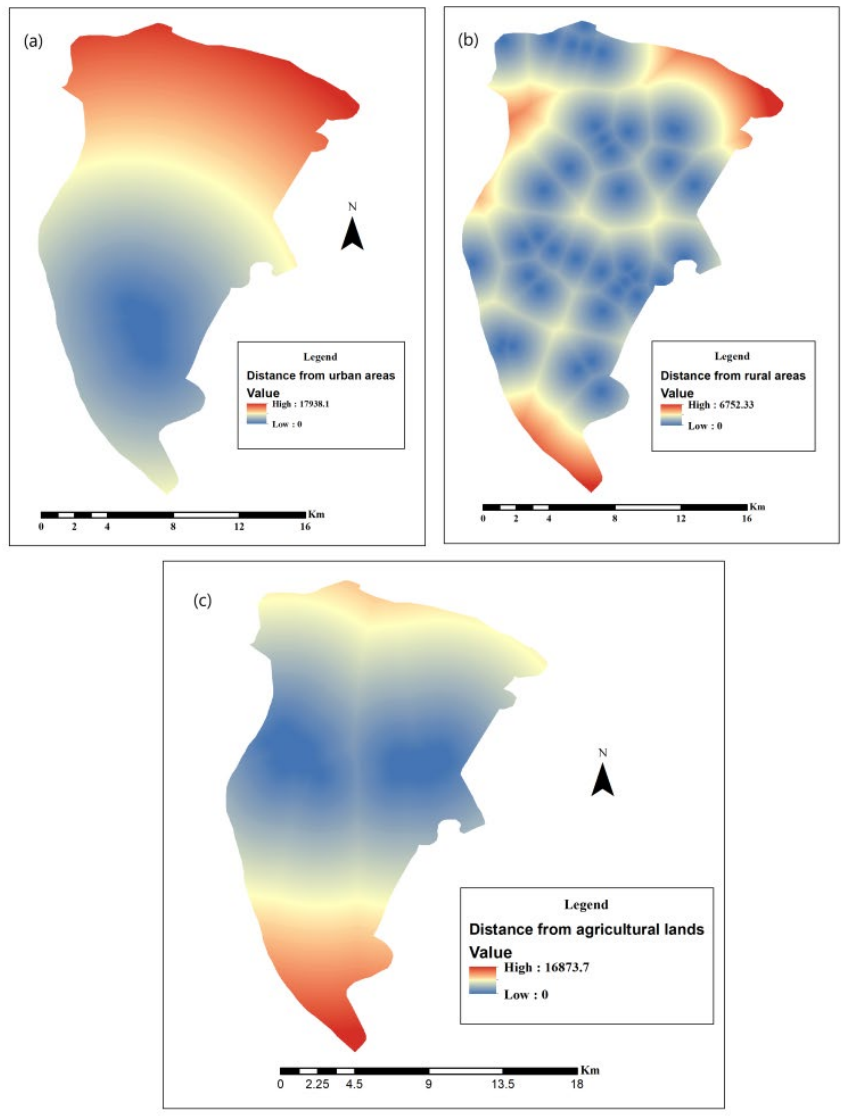

Figure 2. (a) urban areas, (b) Rural areas,(c) agricultural lands

Distance from Industrial areas: There is no industrial town in the study area, except for the oilfields and oil installations in the region where the location of the oil installations was prepared for the overlaying operation and was determined by applying the Euclidean distance function at the regional level. The existence of the centers was restrictive for the landfill. Therefore, according to EPA criteria considered when classifying this feature. The landfill site should be at least $3 \mathrm{~km}$ away from existing areas or future industrial development. Fig. 3 (b) shows the distance from the map of the industrial areas.

Distance to Groundwater: Landfill activities disrupt groundwater resources in the form of leachate movement and waste erosion. Therefore, landfill sites should be selected in distant areas away from groundwater conservation and should be selected in areas where they are sufficiently deep to avoid leachate movement. Landfill sites at a high level of groundwater areas need a particular design. According to literature, there are various conservation distance values for this criterion including, Moghaddas and Namaghi [36] reported a $300 \mathrm{~m}$ buffer conservation zone. Motlagh and Sayadi [37] defined a $250 \mathrm{~m}$ buffer zone and Karimi et al. [38] considered a $400 \mathrm{~m}$ buffer zone around the groundwater resources.

Wherever possible, the landfill site should not be located on important aquifers in the highly vulnerable area. Also, the disposal site should not be selected in an area where the water table has been below $5 \mathrm{~m}$ in-depth for the past 30 years. In order to prepare the water table map of the study area using inquiring from the regional water of the city, the groundwater depth was obtained, and the map was created, as shown in Fig. 4 (a). The result of this study is in agreement with the declarations and findings of Khan and Samadder [39], Yousefi et al. [8], and Manual on Municipal Solid Waste Management [40] on siting MSW landfill. 
Distance to River: Landfill sites release leachate and poisonous gases. Thus, landfill sites should not be considered close to surface water such as ponds, lakes, rivers, and streams [15]. The release of leachate to surface water and groundwater is a crucial issue in irregular landfills and results in various problems with adverse impacts on the environment [41]. Dorhofer and Siebert [42] claim that as landfills produce pernicious gases and leachate, they should not be selected near water wells and surface water bodies. Motlagh and Sayadi [36] reported that a minimum buffer zone of $300 \mathrm{~m}$ should be considered for water bodies (natural or artificial) such as wetlands and, the location suitability for landfills raises with raising distance from water sources.

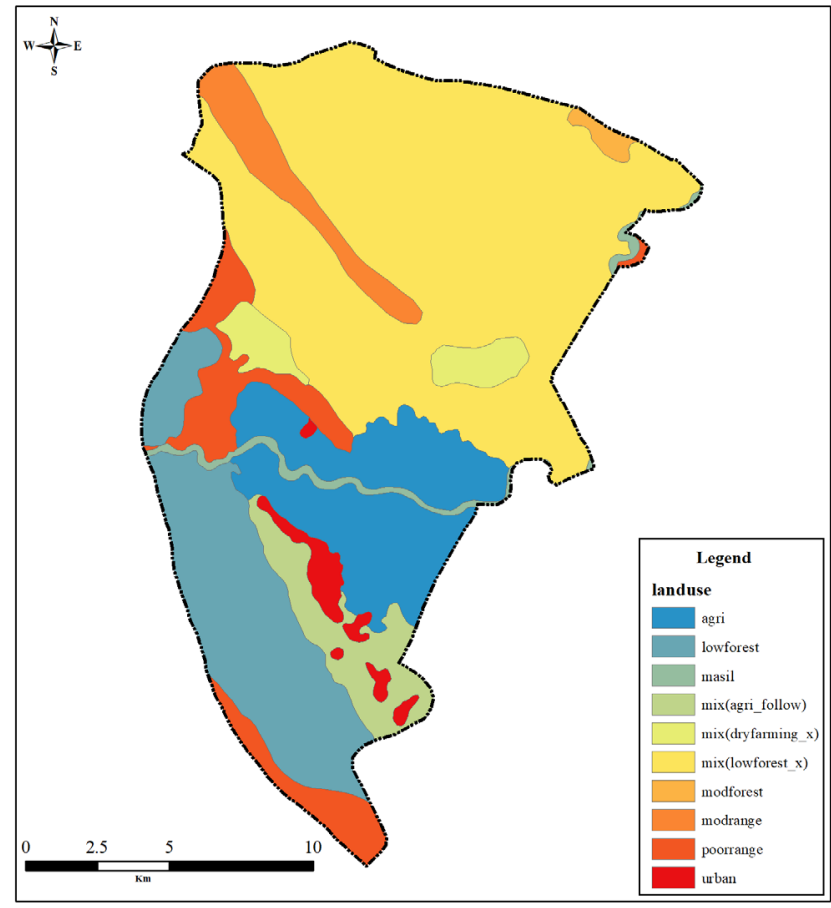

Figure 3. Land use

Thus, in this study, the distance map of each factor was separately prepared, and the distance closer to the surface water sources has less value than the farther distance. Figs. 4(c) shows the distance from the permanent rivers in the study area.
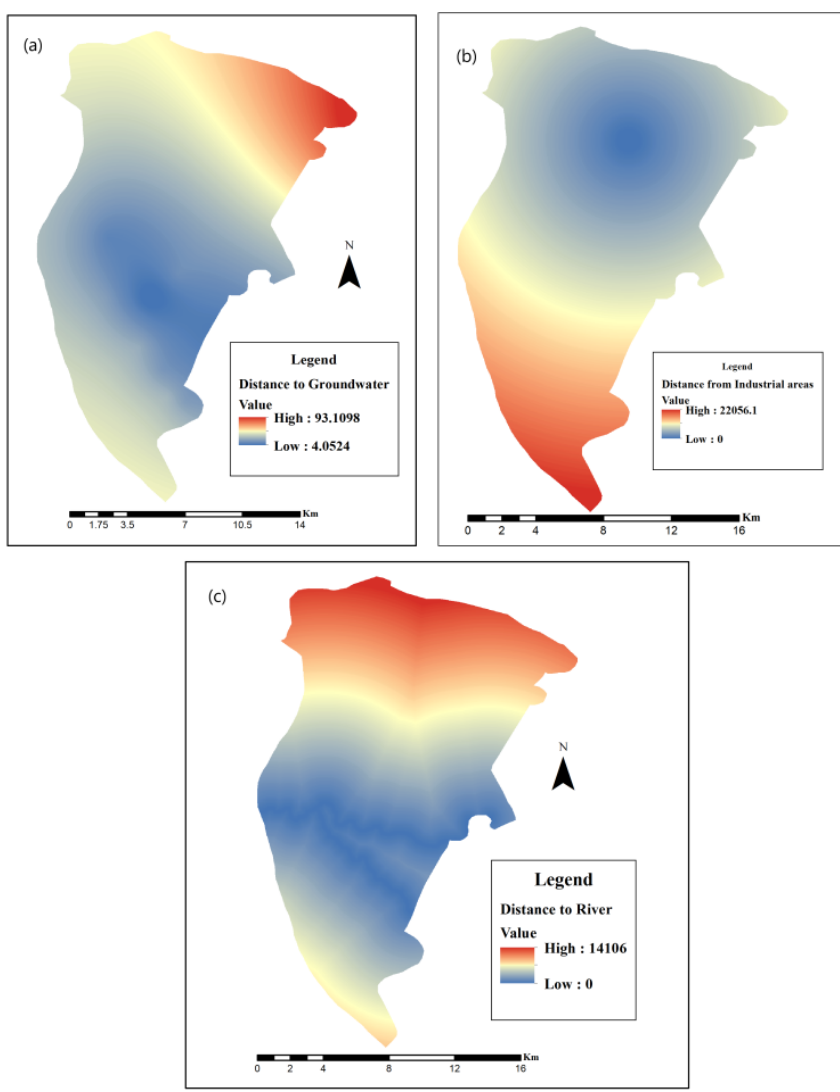

Figure 4. (a) Groundwater, (b) industrial areas, (c)river.

\section{Technical- operational criteria}

Distance to Road: Many scholars have suggested a $1000 \mathrm{~m}$ buffer zone for a landfill site from the road network [43]. However, based on high transportation costs, landfill sites should not be considered too remote from the road, and the suitability ranking of sites decreases the remote they are from the road network [44]. Based on the standard formulated by EPA for landfill site selection, distances from the road less than $100 \mathrm{~m}$ are unacceptable. Areas larger than $2000 \mathrm{~m}$ from the road are less suitable; a distance between $100 \mathrm{~m}$ and $1000 \mathrm{~m}$ could be proposed suitable, which is in agreement with the study of Allen et al. [45] and Khan and Samadder [38] which they reported that areas larger than $1 \mathrm{~km}$ from main roads and highways should not be considered. The most appropriate distance from the road is $251-500 \mathrm{~m}$ which provides easy accessibility and decreases the construction costs of new roads, which agrees with the result of studies made by Karimi et al. [37] and Al-Anbari et al. [46]. Therefore, easy accessibility to the road is a vital parameter for the movement of waste disposal vehicles.

The map of the road network in the study area was prepared from the national road map. In general, for convenience and reduced transportation time and cost, the landfill should have primary and secondary roads and be close to the existing roads as much as possible. In all existing literature, access roads have been considered one of the essential factors in selecting municipal landfill sites. The distance from these features is then calculated using the Eucleadian Distance function, and the distance of pixels from the features is considered the value of each pixel in the corresponding map, and thus, the distance map of each factor was separately prepared (fig. 5a).

Distance to Dam: In addition to the supply of potable and agricultural water downstream, dams severely affect the downstream environment. According to EPA regulations, the disposal site should not be selected in the main dry or flowing branches leading to the dams. For this purpose, the map of distance from the Shahid Nozari reservoir near the study area was drawn, and according to the EPA standards, it should be at least $1 \mathrm{~km}$ away, and the classification was done in this way. Fig. 5(b) shows the map of the distance from the dam. 

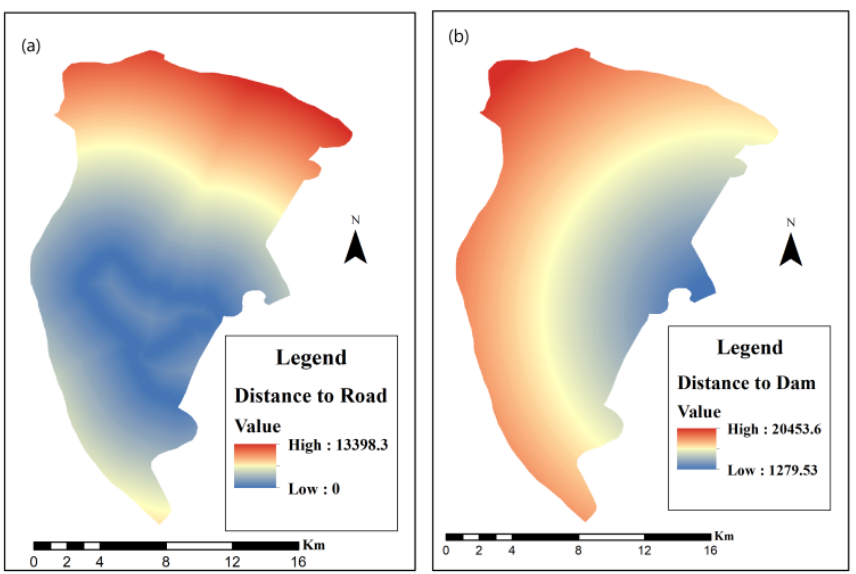

Figure 5. (a) Access road, (b) dam.

\section{Physical criteria}

Slope: The costs of transportation and excavation are increasing due to high slope values [47]. Thus, the slope is a vital economic and technical parameter in landfill site selection. Various slope threshold values have been used to choose a suitable location for the landfill in the literature [24]. Land surface with steep slopes and high elevation is unsuitable for selecting a location for landfill sites [48]. Sener et al [49] suggested that the $8-12 \%$ should be too steep; hence he applied a slope between 0 and 5\%, while Guiqin et al. [47] asserted that areas with $0-10 \%$ slope would be most suitable and $40-50 \%$ problematic areas for landfill site. Karimi et al. [37] also reported that construction costs in areas with highly steep slopes are not optimal economically and should not be planned for selecting an appropriate location for a landfill. Furthermore, Chabuk et al., [5] and Effat and Hegazy [50] considered areas between $0^{\circ}$ and $10^{\circ}$ slopes appropriate for constructing landfill sites, and this showed areas where are almost flat or flat, are a suitable location for considering landfills.

Increasing the slope is of interest from both economic and environmental perspectives because on steep slopes, the landfill is problematic either in terms of leachate flow during rainfall or from the economic view (cost of construction of roads and infrastructure and increased cost of excavation). The steep slope also causes the runoff to flow, leading to the movement of pollutants from point to point. Fig. 6(a) indicates the slope map of the study area. The slope classification is done based on the natural break logic that defines the natural breakpoints.

The Soil type: The soil has a significant impact on the value of the groundwater recharges that can enter the ground, and hence on the ability of contaminants to move vertically into the unsaturated location. Clay and silt are composed of fine particles that can decline relative to soil's permeability and limit the movement of the contaminants [51]. Highly penetrable soils, including clay and clay loam, are unacceptable, while low permeability soils, including clay and clay loam, are acceptable, and relatively low to medium penetrability soil, including sandy clay, are adequately acceptable for landfills [52]. Sharifi and Retsios [53] stated that clay-rich soil with more than 50\% clay, high soil thickness, and shallow penetrability soil with preferably $0.05 \mathrm{~m} /$ day or less should be selected for landfill site construction. Sandy soils should not be considered for landfills due to the high porosity and high-water penetrability rate, enabling landfills to impact the water quality in the area. Furthermore, Motlagh and Sayadi [36] reported that silty clay followed by silty sand is the best soil texture. In this study, soil types that decline the infiltration rate or pollutants leaching from landfill sites are considered a better choice.

One of the major elements contributing to the prevention of leachate infiltration is the type of soil used to cover the waste. The permeability of such soil should remain below. Runoff is said to have a significant impact on the high leachate. The amount of runoff on the land surface depends on the rainfall intensity and length of rainfall. In this regard, the soil permeability, cover, surface slope (2-4\%, and 30\% for lateral slopes), soil quality, and conditions are critical. The study area was divided into four classes according to the considered area, land capability, and type divisions. Then each of the classes assigned scores of 0 to 1 according to the suitability for landfill. Fig. 6(d) indicates the soil map of the study area with the area of each type. It should be noted that the land type map was obtained from the Water and Soil Research Institute.

Geology: In the selection of landfill sites, part of geomorphological studies is related to the geology of the study area. The land as the context and infrastructure of all living and non-living factors directly or indirectly affects the formation and characteristics of all the natural factors. The geological map was first transformed into the raster format and then determined. The range of 0 to 1 was used to represent the rating importance, as shown in Fig. 6 (b). It should be noted that the fault map was obtained from the Geophysics Institute of Tehran University.

Alluvial fans: The present-day alluvial deposits are the youngest sediments in the region, deposited in low and relatively flat areas and plains, valleys and mountains, beaches, and river beds.

Aghajari formation: belongs to the upper Miocene and lower Pliocene. This formation is composed of calcareous sandstones and red conglomerates, and a period of marl and silt. The dissolution of the sediments causes the deterioration of water quality.

Gachsaran formation: is temporally equivalent to Razak formation and belongs to a shallow sedimentary environment. This formation is mainly observed at low heights.

Mishan formation: typically contains silt, sandstone, and conglomerate with radiolarite pebbles, especially the abundant chert, which becomes coarse-grained upward.

Bakhtiari formation: consists of medium-thick calcareous gray layers and assemblages of alveolinid, nummulite, and assilinid fossils.

Distance to Fault: It is not suggested that landfill sites be considered in areas with active geological formations or other subsurface topographies. Hence, areas with dormant or active faults are recommended as unsuitable locations for landfill construction [54]. Avoiding faults plays a vital role in contamination prevention resulting from seismic activity. Groundwater may be polluted due to leachate since fault areas rise the permeability of rocks [18]. The seismic hazard and possibly unstable land area are essential parameters for decision-makers when selecting landfill sites. In addition, areas with active or potentially active landslides are unsuitable for landfill sites [36]. Landfill sites should be considered at a location remote from fault lines to decline the possibility of natural disasters.

The disposal site should not be located in the direction and area of known active faults and hidden faults. The disposal site should also be $200 \mathrm{~m}$ away from the predictable range for the seismic hazards. For this purpose, the fault map of the area was prepared and classified according to EPA regulations, as shown in Fig. 6(e). It should be noted that the fault map was obtained from the Geophysics Institute of Tehran University.

Distance to floodplain: Any area with frequent or periodic flooding is inappropriate for a landfill site. To prevent the risk of overland drainage contamination, a landfill should not be considered near a floodplain [55]. Areas situated in the 100-year floodplain are therefore unsuitable for selecting landfill sites since the floodplains of major rivers may depict a threat to the stability of the waste dumped in the landfill. Thus, landfills should not be considered within $300 \mathrm{~m}$ of a major river [47].

Hydrology of surface water is vital in establishing and deploying existing natural drainage and surface runoff characteristics, which should be considered. Other flood characteristics (e.g., 100-year flood return period) should also be specified. Due to the control measures that should be developed to divert surface runoff from the landfill site, 
designers should pay special attention to identifying existing and temporary water channels and the surface and characteristics of distributed culverts [56]. Various factors such as thunderstorms and occasional rain, the great extent of watersheds upstream of rivers, impermeable formations such as marl, salt, and gypsum formations, and poor vegetation have caused destructive flooding in the low and flat areas around the permanent rivers. For this criterion, the minimum distance to the flood-prone areas is $81 \mathrm{~m}$, and as the distance increases, the suitability also increases. As such, the Euclidean distance map was separately prepared, and the distance closer to the flood-prone areas has less value than the farther distance in the standardized map, and the greater the distance, the more appropriate the site for landfill. Fig. 6 (c) shows the area map and the classification of flood-prone areas.
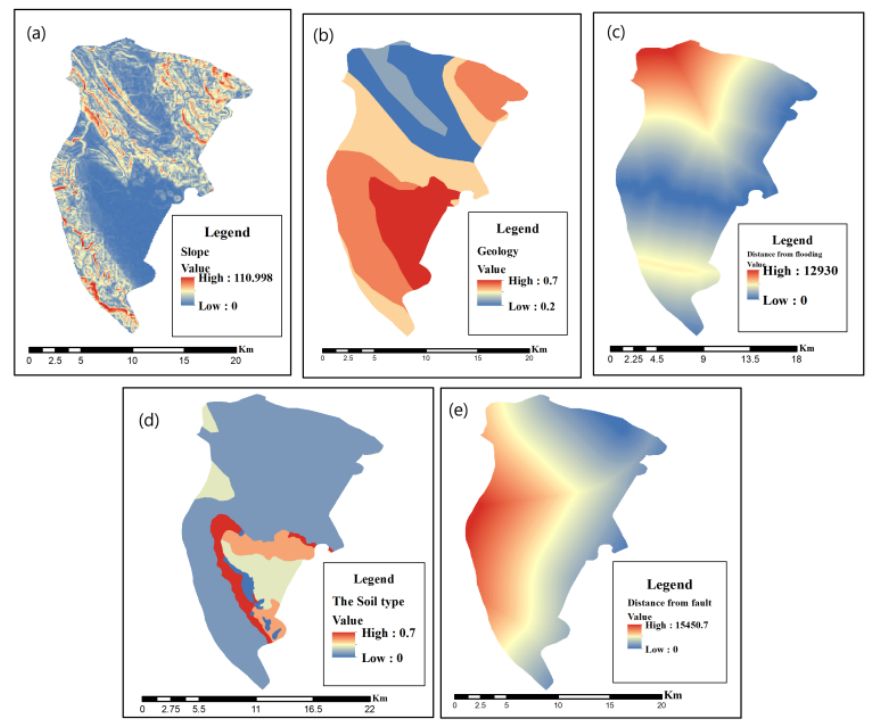

Figure 6. (a) slope, (b) Geology, (c) flood-prone areas, (d) soil type, (e) fault.

\subsection{Weighting}

A weighted linear combination was applied to make the landfill suitability map. This approach is one of the most widely used methods in MCDA. This technique enables the possibility of criteria standardization in continuous scales and hence has more flexibility than other methods, including Boolean and Overlay. Also, in this approach, each factor allocates its specific weight and can be placed in a comparative range with other factors [37]. Investigations carried out by researchers including Aydi et al. [51], and Shahabi et al. [57] indicated that locating landfill site weighted linear combination had better decision-making powers than other MCDA techniques such as Boolean logic.

After identifying the influential factors in the success of a construction or research project related to location, it is necessary to evaluate the effectiveness using appropriate tools. In addition to prioritizing the criteria and sub-criteria affecting the landfill site based on the calculated weight, a new model is proposed according to managers and experts of this research for locating such projects.

At this stage of the study, the pairwise comparison matrix was developed based on the hierarchical model, the weight of the criteria was calculated, and finally, the consistency rate was estimated (Table 2). As such, after preparing the relevant questionnaire (expert questionnaire) and using the opinion of urban planning experts to develop the pairwise comparison matrix of criteria and sub-criteria, the relevant weights were determined using Expert Choice software, and the software capability was utilized to calculate the inconsistency rate, which is the main parameter for the accuracy of the weighing results. The statistical population of the experts used for the weighting of criteria (AHP) consisted of 16 experts in municipal waste site selection and management.
Table 2: Standardizing according to the type of sub-criteria

\begin{tabular}{|c|c|c|c|}
\hline Criteria & Abbreviation & Criteria & Abbreviation \\
\hline Urban areas & UR & $\begin{array}{c}\text { Groundwater } \\
\text { depth }\end{array}$ & GW \\
\hline Rural areas & VI & Access road & RO \\
\hline $\begin{array}{l}\text { agricultural } \\
\text { land }\end{array}$ & AG & Dam & DA \\
\hline Surface water & WA & Slope & SL \\
\hline Land use & LU & Soil & so \\
\hline Industrial use & IN & Fault & FA \\
\hline Flooding & FL & Geology & $\mathrm{GE}$ \\
\hline
\end{tabular}

Based on the results, the sub-criterion of distance from the river was identified as the most critical parameter, followed by the groundwater depth, and the flooding parameter was the least important factor. Also, the inconsistency coefficient was calculated to be 0.4 , indicating the suitable consistency of all judgments.

\subsection{Map integration operation}

In this study, many parameters were considered for landfill site selection, and these parameters were made in a multi-criteria structure. These parameters were classified into four groups, namely environmental criteria (distance to industrial centers, distance to river, land use, and distance to groundwater resources), Technicaloperational criteria (distance to dam and distance to the road), Socioeconomic criteria (distance to residential areas (urban and rural) and distance to agricultural lands) and Physical criteria (distance to faults, soil texture, geology, slope and distance to flood-prone areas). In common with this study, similar investigations were carried out and selected various criteria, including environmental, economic, and social criteria. In particular, Kapilan and Elangovan [27] and Motlagh and Sayadi [36] considered environment and economic criteria and the sub-criteria to locate the best sites for the landfill in different regions. Furthermore, because of the lack of airports and historical places in the study area, these parameters were not considered in landfill site selection and were not suitable. Also, we did not consider the wind parameter since, in the study area, the wind blows to the west and northeast sides which there were no residential areas in the wind direction.

In order to overlay the maps in the GIS environment, the criteria were first standardized and nondimensionalized so that they could be integrated. There are many techniques through which these operations are performed. In the fuzzy method used in this study, standardization is performed in the range of 0 to 1 . The breakpoints should be specified to determine what type of operation to be used for the standardization.

At this stage, they were standardized according to the type of subcriteria and the suitable distance, and the fuzzy maps are given in the previous section. After the standardization of the mathematical model, the composition and integration of the layers are determined as follows. Finally, the layers are overlaid to obtain the suitability of the intended area in terms of land use for the landfill site. In this way, by applying the Map algebra function, the layers were integrated, and the resulting class map is as follows.

The final map was classed into five levels: very low suitability, low suitability, moderate suitability, high suitability, and very high suitability (Table. 3). The very high suitability locations are patches mainly found in the central part of the study area. These locations have an ideal distance to residential areas, and they are undeveloped lands and lack surface and groundwater resources nearby. Field observations were conducted to examine the suitability of these locations. The final site has been selected according to some 
parameters, including land property, political issues, soil covering landfill cells, and public acceptance.

Table 3: Class and score of total risk.

\begin{tabular}{ccc}
\hline Suitability Class & Area (hectare) & Area Percentage \\
\hline Very low suitability & 2509.7 & 8.58 \\
Low suitability & 10377.0 & 35.48 \\
Moderate suitability & 14711.9 & 50.30 \\
High suitability & 1413.8 & 4.83 \\
Very high suitability & 235.5 & 0.81 \\
\hline
\end{tabular}

The final map review shows that the moderate suitability class with $50 \%$ of the area has the highest class and the very high suitability with $0.8 \%$ has the least area (fig. 7 ).

The results show that the nearest residential area $1200 \mathrm{~m}$ away from the selected area is the Shahbazkhani village, and the selected site is situated at a distance of $1600 \mathrm{~m}$ from Bureki and $2000 \mathrm{~m}$ from Karei. The site's access road near Bureki is $305 \mathrm{~m}$ away from the access road and $1100 \mathrm{~m}$ away from Marei. The selected site is under state ownership.

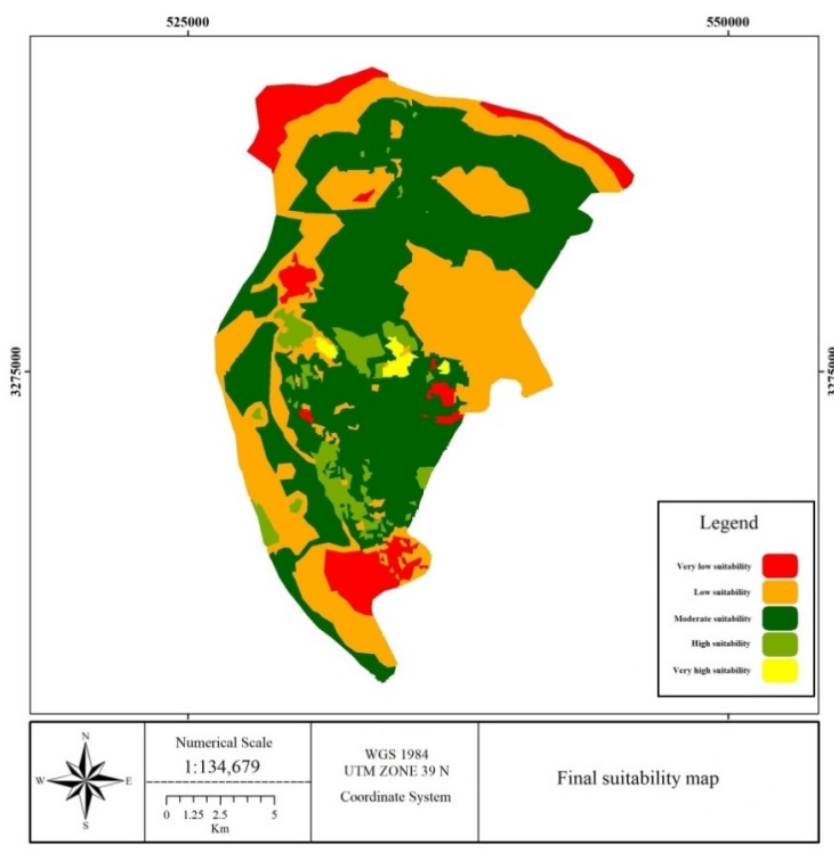

Figure. 7 Landfill suitability map based on AHP analysis

The final map review shows that, in total, two suitable classes cover an area of about $5.6 \%$ of the region, which is close to $1 \%$ in the classical environmental approach, indicating that the AHP method selected more areas and the environmental approach is more stringent. According to the results of this study, the sub-criteria of distance from the river is identified as the most critical parameter, followed by the depth of groundwater, and the least important factor is the flooding parameter. In addition, the inconsistency coefficient was calculated to be 0.40 , indicating the consistency suitability of all judgments. The final map also shows that the moderate suitability class with $50 \%$ of the area had the highest class, and the very high suitability with $0.8 \%$ had the lowest area. Finally, the results show that the nearest residential area $1200 \mathrm{~m}$ away from the selected area is the Shahbazkhani village. Also, the selected site is situated at a distance of $1600 \mathrm{~m}$ from Bureki and $2000 \mathrm{~m}$ from Karei.
The result of this study in the potential of applying GIS and MCDA in the landfill site selection agrees with a similar study Vučijaka et al. [58] reported that a combination of MCDA and GIS has an excellent capability in landfill site selection. Likewise, Kharat et al. [59] indicated that the combination of GIS and MCDA has a high capacity to analyze land suitability for locating a suitable site for a landfill.

\section{Conclusion}

Management and planning start with description problems and continue with different analyses, such as modeling and simulation. There are multiple models and techniques for the excellent selection of appropriate sites for disposing of urban wastes. This study conducted the MCDA method used in a GIS environment to study the best location for landfill sites in the Khesht city, Fars province, Iran. The selection of landfill sites is a complex work that needs consideration of many criteria to select the ideal sites by integrated techniques. Based on expert judgment and previous studies, this study analyzed fifteen different parameters in environmental, technical-operational, physical, and socio-economic groups. Also, field observations were conducted for data validation and indicated good agreement with the GIS-based suitability mapping. Different layers were standardized according to the suitability for the landfill after obtaining from different organizations and preparation in the ArcGIS software environment. Next, using the experts' opinions, the weighting of the criteria and sub-criteria was performed, and the relative importance of each one was determined to overlay the layers. The inconsistency rate was equal to 0.04 , which represents the high consistency of matrices. Then, the overlaying was performed, and three sites were identified as the best place for a landfill in the Khesht district.

Obviously, it is essential to use GIS analysis tools and other modern scientific methods. This study shows that AHP is a flexible, easy-toimplement, and straightforward method of landfill site selection and is very efficient in integrating powerful GIS tools. According to the research findings, it can be stated that the application of AHP in environmental planning is critical because it makes the subjective decisions quantitative and minimizes the errors between the comparison of criteria. It helps planners transform a complex natural problem into a hierarchical structure and solve it with sufficient speed and precision. Using this approach makes environmental planning science more practical and successful than ever in crisis planning and management. The preliminary results indicate that the results of the AHP method suggest other areas while selecting the landfill site in a good area. Therefore, the mapping and site selection operations were performed using the GIS using the AHP based on four basic physicals, technical-operational, environmental and socioeconomic criteria, and 14 sub-criteria. The weighting of the layers showed that the layer of distance from the surface water sources was the most critical layer and the distance from the flood-prone areas was the least important one. After applying the site-selection criteria in the GIS system, completing the database, and weighting the criteria, many study areas were classified as undesirable and could not be used for the landfill and were removed.

\section{Declaration of Conflict of Interests}

The authors declare that there is no conflict of interest. They have no known competing financial interests or personal relationships that could have appeared to influence the work reported in this paper. 


\section{References}

[1.] Ferronato N, Torretta V, Ragazzi M, Rada EC (2017). Waste mismanagement in developing countries: a case study of environmental contamination. UPB Sci Bull Ser D 79:185-196. doi:10.3390/ijerph16061060

[2.] Abdel-Shafy HI \& Mansour MSM (2018). Solid waste issue: Sources, composition, disposal, recycling, and valorization, Egypt. J. Petrol. https://doi.org/10.1016/j.ejpe.2018.07.003.

[3.] Saaty T. (1997). A Scaling Method for Priorities in Hierarchical Structures. J. Match. Psychology, 15: 234-281. 1997 Doi.org/10.1016/0022-2496 (77)90033-5

[4.] Kontos TD, Komilis DP, Halvadakis CP (2005) Siting MSW landfills with a spatial multiple criteria analysis methodology. Waste Manag 25(8):818-832

[5.] Chabuk AJ, Al-Ansari N, Hussain HM, Knutsson S, Pusch R (2017) GIS-based assessment of combined AHP and SAW methods for selecting suitable sites for landfill in Al-Musayiab Qadhaa, Babylon, Iraq. Environ Earth Sci 76(5):209

[6.] Solangi YA, Shah SAA, Zameer H, Ikram M, Saracoglu BO (2019) Assessing the solar PV power project site selection in Pakistan: based on AHP-fuzzy VIKOR approach. Environ Sci Pollut Res 26(29):30286-30302

[7.] Saaty TL (1980) The analytic hierarchy process. McGraw-Hill International, New York, p 287

[8.] Yousefi H, Yousefi-Sahzabi A, Masih M, Ghaleh S, Mirzaaghabeik M (2017) Urban parks prioritization concerning the age-friendly criteria in Sari, Northern Iran. Int J Occup Hyg 8:116-123

[9.] Lyu HM, Shen JS, Arulrajah A (2018) Assessment of geohazards and preventative countermeasures using AHP incorporated with GIS in Lanzhou, China. Sustainability 10:304-311. https://doi.org/10.3390/su10020304

[10.] Ali S, Lee SM, Jang CM (2017) Determination of the most optima on-shore wind farm site location using a GIS-MCDM methodology: evaluating the case of South Korea. Energies 10:2072-2089. https://doi.org/10.3390/en10122072

[11.] Bhushan N, Rai K (2004) Strategic decision making: applying the analytic hierarchy process. Springer, New York, p 172

[12.] Vaidya O V, Kumar S. (2004). Analytic hierarchy process: An overview of applications, April. DOI: 10.1016/j.ejor.2004.04.028

[13.] Haile G, Suryabhagavan KV (2019) GIS-based approach for identification of potential rainwater harvesting sites in Arsi Zone, Central Ethiopia. Model. Earth Syst. Environ. 5, 353-367 (2019). https://doi.org/10.1007/s40808-018-0537-7

[14.] Khan MMUH, Vaezi M, Kumar A (2018) Optimal siting of solid waste-to-value-added facilities through a GIS-based assessment. Sci. Total Environ. 610-611, 1065-1075. https://doi.org/10.1016/i.scitotenv.2017.08.169.

[15.] 15. Demesouka OE, Anagnostopoulos KP, Siskos E (2019) Spatial multi-criteria decision support for robust land-use suitability: the case of landfill site selection in Northestern Greece. Eur. J. Oper. $\quad$ Res. $272 \quad$ (2), 574-586. https://doi.org/10.1016/j.ejor.2018.07.005.

[16.] Saaty RW (1987) The analytic hierarchy process-what it is and how it is used. Math Model 9(3-5):161-176

[17.] Zheng HW, Shen GQ, Wang H, Hong J (2015) Simulating land use change in urban renewal areas: A case study in Hong Kong. Habitat Int. 2015, 46, 23-34. https://doi.org/10.1016/j.habitatint.2014.10.008

[18.] Moeinaddini M, Khorasani N, Danehkar A, Darvishsefat AA Zienalyan M (2010) Siting MSW landfill using weighted linear combination and analytical hierarchy process (AHP) methodology in GIS environment (case study: karaj). Waste Manage

https://doi.org/10.1016/j.wasman.2010.01.015

[19.] Sener B, Süzen M, Doyuran V (2006) Landfill site selection by using geographic information systems. Environ Geol 49:376-388. https://doi.org/10.1007/s00254-005-0075-2

[20.] Karakuş CB, Demiroğlu D, Çoban A, Ulutaş A (2019) Evaluation of GIS based multi criteria decision making methods for sanitary landfill site selection: the case of Sivas city, Turkey. Journal of Material Cycles and Waste Management. https://doi.org/10.1007/s10163-019-00935-0

[21.] Adewumi JR, Ejeh OJ, Lasisi KH, Ajibade FO (2019) A GIS-AHP based approach in siting MSW landfills in Lokoja, Nigeria. SN Applied Sciences (2019) 1:1528. https://doi.org/10.1007/s42452019-1500-6

[22.] Kamdar I, Ali S, Bennui A, Techato K, Jutidamrongphan W (2019) Municipal solid waste landfill siting using an integrated GIS-AHP approach: A case study from Songkhla, Thailand. Resources, Conservation \& Recycling $149 \quad$ (2019) 220-235. https://doi.org/10.1016/i.resconrec.2019.05.027

[23.] Barakat A, Hilali A, El Baghdadi M, Touhami F (2017) Landfill site selection with GIS-based multi-criteria evaluation technique. A case study in Béni Mellal-Khouribga Region, Morocco. Environ Earth Sci 76:413. https://doi.org/10.1007/s12665-017-6757-8

[24.] Islam A, Ali SM, Afzaal M, Iqbal S, Zaidi SNF (2018) Landfill sites selection through analytical hierarchy process for twin cities of Islamabad and Rawalpindi, Pakistan. Environ Earth Sci 77:72.

[25.] Khodaparast M, Rajabi AM, Edalat A (2018) Municipal solid waste landfill siting by using GIS and analytical hierarchy process (AHP): a case study in Qom city, Iran. Environ Earth Sci 77:52. https://doi.org/10.1007/s12665-017-7215-3

[26.] 26. Eskandari M, Homaie M. Pazira E, Van Genuchten M TH (2015). Optimizing landfill site selection by using land classification maps.springer_Verlag Berlin HEIDELBERG 2015. DOI: $10.1007 / \mathrm{s} 11356-015-4182-7$

[27.] Kapilan S, Elangovan K (2018) Potential landfill site selection for solid waste disposal using GIS and multi-criteria decision analysis (MCDA). J. Cent. South Univ. 25, 570-585 (2018). https://doi.org/10.1007/s11771-018-3762-3

[28.] Santhosh LG, Sivakumar BG (2018) Landfill site selection based on reliability concepts using the DRASTIC method and AHP integrated with GIS-a case study of Bengaluru city, India. Georisk Assess Manag Risk Eng Syst Geohazards 12(3):234-252. https://doi.org/10.1080/17499 518.2018.14345 48

[29.] Krčmar D, Tenodi S, Grba N, Kerkez D, Watson M, Rončević S Dalmacija B (2018) Preremedial assessment of the municipal landfill pollution impact on soil and shallow groundwater in Subotica, Serbia. Sci. Total Environ. 615, 1341-1354. https://doi.org/10.1016/j.scitotenv.2017.09.283.

[30.] Ananda J, Herath G. (2005) The use of analytic hierarchy process to incorporate stakeholder preferences into regional forest planning. Forest Policy and Economics 5: 13- 26. DOI: 10.1016/S1389-9341(02)00043-6

[31.] Nas B, Cay T, Iscan F, Berktay A (2010) Selection of MSW landfill site for Konya, Turkey using GIS and multi-criteria evaluation. Environ. Monit. Assess. 160 (1-4), 491-500. https://doi.org/10.1007/s10661-008-0713-8.

[32.] Zanjani AJ, Rezaei M (2017) Landfill site selection using combination of fuzzy logic and multiattribute decision-making approach. Environ Earth Sci 76:448. https://doi.org/10.1007/s12665-017-6774-7 
[33.] Adewumi JR, Akomolafe JK, Ajibade FO (2017b). Development of flood prone area map for Igbokoda Township using geospatial technique. J. Appl. Sci. Proc. Eng. 4 (2), 158-178. https://doi.org/10.33736/jaspe.433.2017

[34.] Ajibade FO, Olajire OO, Ajibade TF, Nwogwu NA, Lasisi KH, Alo AB, Owolabi TA, Adewumi JR (2019) Combining multi-criteria decision analysis with GIS for suitably siting landfills in a Nigerian state. Environmental and Sustainability Indicators 3-4 (2019) 100010. https://doi.org/10.1016/j.indic.2019.100010

[35.] Moghaddas NH, Namaghi HH (2011) Hazardous waste landfill site selection in Khorasan Razavi province, northeastern Iran. Arab J Geosci 4(1-2):103-113. https://doi.org/10.1007/s12517-0090083-8

[36.] Motlagh ZK, Sayadi MH (2015) Siting MSW landfills using MCE methodology in GIS environment (case study: Birjand plain, Iran). Waste Manag 46:322-337. https://doi.org/10.1016/j.wasman.2015.08.013

[37.] Karimi H, Amiri S, Huang J, Karimi A (2019) Integrating GIS and multi-criteria decision analysis for landfill site selection, case study: Javanrood County in Iran. Int J Environ Sci Technol 16(11):7305-7318. https://doi.org/10.1007/s13762-018-2151-7

[38.] Khan D, Samadder SR (2015) A simplified multi-criteria evaluation model for landfill site ranking and selection based on $A H P$ and GIS. J Environ Eng Landsc Manag. https://doi.org/10.3846/16486 897.2015.1056741

[39.] Manual on Municipal Solid Waste Management (2000) Central Public Health and Environmental Engineering Organisation (CPHEEO), 1st edn, Lecture of the Ministry of Urban Development, Government of India, New Delhi

[40.] 40. Atta M, Yaacob WZW, Jaafar OB (2015) The potential impact of leachate-contaminated groundwater of an ex-landfill site at Taman Beringin Kuala Lumpur, Malaysia. Environ Earth Sci 73:3913-3923. https://doi.org/10.1007/s12665-014-3675-x

[41.] Dorhofer G, Siebert H (1998) The search for landfill sites requirements and implementation in Lower Saxony, Germany. Environ Geol 35(1):55-65. https://doi.org/10.1007/s0025 40050 292

[42.] Al-Hanbali A, Alsaaideh B, Kondoh A (2011) Using GIS-Based weighted linear combination analysis and remote sensing techniques to select optimum solid waste disposal sites within Mafraq City, Jordan. J. Geogr. Inf. Syst. 3 (4), 267-278. https://doi.org/10.4236/jgis.2011.34023.

[43.] Yal GP, Akgün H (2014) Landfill site selection utilizing TOPSIS methodology and clay liner geotechnical characterization: a case study for Ankara, Turkey. Bull. Eng. Geol. Environ. 73 (2), 369-388. https://doi.org/10.1007/s10064-013-0562-8.

[44.] Allen A, Brito G, Caetano P, Costa C, Cummins V, Donelly J, Fernandes C, Koukoulas S, O'Donnell V, Robalo C, Vendas D (2002) Procedure for the location of landfill sites using a GIS model. In: Proceedings of 9th Congress of the International Association for Engineering Geology and the Environment, Durban, South Africa, 16 - 20 September 2002, pp. 2704-2713.

[45.] Al-Anbari MA, Al-Ansari N, Jasim HK (2014) GIS and multicriteria decision analysis for landfill site selection in AlHashimyah Qadaa. Natl Sci 6:282-304. https://doi.org/10.4236/ns.2014.65032

[46.] Guiqin W, Li Q, Guoxue L, Lijunc C (2009) Landfill site selection using spatial information technologies and AHP: a case study in Beijing, China. Environ. Manag. 90 (8), 2414-2421. https://doi.org/10.1016/j.jenvman.2008.12.008

[47.] Şener Ş, Şener E, Nas B, Karagüzel R (2010) Combining AHP with GIS for landfill site selection: a case study in the Lake Beysehir catchment area (Konya, Turkey). Waste Manag. 30 (11), 2037 2046. https://doi.org/10.1016/j.wasman.2010.05.024.
[48.] Şener B, Süzen ML Doyuran V (2006) Landfill site selection by using geographic information systems. Environ Geol 49, 376-388 (2006). https://doi.org/10.1007/s00254-005-0075-2

[49.] Effat HA, Hegazy MN (2012) Mapping potential landfill sites for North Sinai cities using spatial multi-criteria evaluation. Egypt. J. Remote Sens. Sp. Sci. 15 (2), 125-133. https://doi.org/10.1016/j.ejrs.2012.09.002.

[50.] 50. Lee S (2003) Evaluation of waste disposal site using the DRASTIC system in Southern Korea. Environ. Geol. 44 (6), 654664. https://doi.org/10.1007/s00254-003-0803-4.

[51.] Aydi A, Zairi M, Dhia HB (2013) Minimization of environmental risk of landfill site using fuzzy logic, analytical hierarchy process, and weighted linear combination methodology in a geographic information system environment. Environ. Earth Sci. 68 (5), 1375-1389. https://doi.org/10.1007/s12665-012-1836-3.

[52.] Sharifi M, Retsios V (2004) Site selection for waste disposal through spatial multiple criteria decision analysis. J. Telecom. Info. Tech. 28-38. https://doi.org/10.1016/j.wasman.2011.09.023.

[53.] Eskandari M, Homaee M, Mahmodi S (2012) An integrated multi criteria approach for landfill siting in a conflicting environmental, economical and socio-cultural area. Waste Manag. $\quad 32 \quad$ (8), $1528-1538$. https://doi.org/10.1016/j.wasman.2012.03.014.

[54.] Lin HY, Kao JJ (2005) Grid-based heuristic method for multifactor landfill siting. J. Comput. Civ. Eng. 19 (4), 369-376. https://doi.org/10.1061/(ASCE)0887-3801(2005)19:4(369).

[55.] Tchobanoglous G, Kreith F (2010). Handbook of Solid Waste Management. Translated by Mohammad Reza Khani et al. Tehran: Publications of Municipality and Rural Administration Organization and Khaniran Publications, 2010.

[56.] Shahabi H, Keihanfard S, Ahmad B, Amiri M (2013) Evaluating Boolean, AHP and WLC methods for the selection of waste landfill sites using GIS and satellite images. Environ Earth Sci 71:4221. https://doi.org/10.1007/s1266 5-013-2816-y

[57.] Vučijaka B, Kurtagić S, Silajdžićb I (2016) Multi criteria decision making in selecting best solid waste management scenario: a municipal case study from Bosnia and Herzegovina. Spec Sustain Dev Energy Water Environ Syst 130:166-174. https://doi.org/10.1016/j.wasma n.2010.01.015

[58.] Kharat MG, Kamble SJ, Raut RD et al (2016) Modeling landfill site selection using an integrated fuzzy MCDM approach. Model Earth Syst Environ 2:53. https://doi.org/10.1007/s4080 8-0160106-x

\section{How to Cite This Article}

Dashtian, A., Rouhani, A., Dashtian, A., Municipal Solid Waste Disposal Site Selection Using Remote Sensing Technology and AHP Process (Case Study: Khesht city, Fars Province, Iran), Brilliant Engineering, 2 (2022), 1-10. https://doi.org/10.36937/ben.2021.4535 